\title{
Response of different wheat varieties to various seed rates
}

\author{
Wajid Ali Shah ${ }^{1}$, Zafar Hayat ${ }^{1}$, Ikram Ullah ${ }^{2}$, Shazma Anwar ${ }^{2}$ and \\ Babar Iqbal ${ }^{2 *}$ \\ 1. Department of Agronomy, Bacha Khan University - Charsadda - Pakistan \\ 2. Department of Agronomy, University of Agriculture, Peshawar - Pakistan \\ *Corresponding author's email: agronomist19388@yahoo.com \\ Citation \\ Wajid Ali Shah, Zafar Hayat, Ikram Ullah, Shazma Anwar and Babar Iqbal. Response of different wheat \\ varieties to various seed rates Pure and Applied Biology. Vol. 5, Issue 3, pp529-537. \\ http://dx.doi.org/10.19045/bspab.2016.50067
}

\begin{tabular}{llll}
\hline \hline Received: 24/12/2015 & Revised: 26/05/2016 & Accepted: 02/06/2016 & Online First: 17/06/2016 \\
\hline \hline
\end{tabular}

\section{Abstract}

Experiment was conducted to study the response of different wheat varieties to various seed rates. The experiment consists of five different wheat varieties $\left(\mathrm{V}_{1}=\right.$ Nasir $-2 \mathrm{k}, \mathrm{V}_{2}=$ Salim $2 \mathrm{k}, \mathrm{V}_{3}=$ Bakhtawar-92, $\mathrm{V}_{4}=$ Fakhre-e-Sarhad and $\mathrm{V}_{5}=$ Lucky J-03) were sown at five various seed rates $\left(\mathrm{S} 1=60 \mathrm{~kg} \mathrm{ha}^{-1}, \mathrm{~S}_{2}=80 \mathrm{~kg} \mathrm{ha}^{-1}, \mathrm{~S}_{3}=100 \mathrm{~kg} \mathrm{ha}^{-1}, \mathrm{~S}_{4}=120 \mathrm{~kg} \mathrm{ha}^{-1}\right.$ and $\mathrm{S}_{5}=140 \mathrm{~kg}$ $\left.\mathrm{ha}^{-1}\right)$. Data recorded from the varieties treatments revealed that maximum tillers $\mathrm{m}^{-2}$ (377), leaf area index (4.10), grains spike $\mathrm{s}^{-1}(68), 1000$-grain weight $(45.24 \mathrm{~g})$, grain yield (4022 kg ha-1), biological yield (16660 kg ha' ${ }^{-1}$ ), net income (Rs. 61921), BCR (4.99\%) and MRR \% (499.49) was noted from the plots sown with variety Fakhr-e-Sarhad. Statistical analysis of the data also revealed that seed rates were significantly affected all parameters except biological yield and harvest index. It can be inferred from the data showed that maximum ((369) tillers $\mathrm{m}^{-2}$, grains $\operatorname{spike}^{-1}(65)$, leaf area index (4.03), 1000-grain weight (45.30 g), grain yield (4222 $\left.\mathrm{kg} \mathrm{ha}^{-1}\right)$, biological yield (15030 kg ha $\left.{ }^{-1}\right)$, net income (Rs. 62119), BCR (5.18\%) and MRR \% (518.03) was noted from the plots seeded with $120 \mathrm{~kg} \mathrm{ha}^{-1}$. In case of interaction between varieties and seed rate it was observed that maximum (420.25) tillers $\mathrm{m}^{-2}$, leaf area index (4.79), grains spike ${ }^{1}$ (74), 1000-grain weight (47.33 g), grain yield (4676 kg ha-1), biological yield (19535 kg ha${ }^{1}$ ), net income (Rs. 66863), BCR (5.47\%) and MRR \% (546.95) was noted from the plots sown with FakhreSarhad and seed rate was used at120 $\mathrm{kg} \mathrm{ha}^{-1}$.

Key words: Seed rates; Leaf area index; Yield and yield components; Economic analysis

\section{Introduction}

The yielding ability of a variety is the result of its interaction with the environment. The cultivar and environmental interactions are of major importance in developing improved varieties for a certain locality. The variations in environments have been used effectively to reduce the cultivarenvironment interaction. The region for which an agronomist is developing a variety can often be so sub-divided that all the environments in the region are somewhat similar. This change usually is based on such macro-environmental differences as temperature gradients, rainfall distribution and soil types.

Plant density is one of the major factors determining the ability of the crop to capture resources. It is of particular importance in wheat production because it is under the farmer's control in most cropping systems. Optimum plant densities vary greatly between areas according to climatic conditions, soil, sowing time, and varieties. Consequently, there is value in defining relationships between density and 
wheat yield to establish optimum seeding rates for various regions. Therefore, this study was conducted at Agricultural Research Station, Serai Nourang (Bannu), to check the best performance of wheat varieties sown under different seed rates.

\section{Materials and methods}

The main objective of this study was to evaluate the performance of different wheat varieties using various seed rates for better yield under suitable environmental condition in District Bannu-Khyber Pukhtoonkhwa - Pakistan. Five wheat varieties $\left(\mathrm{V}_{1}=\right.$ Nasir $-2 \mathrm{k}, \mathrm{V}_{2}=$ Salim $-2 \mathrm{k}$, $\mathrm{V}_{3}=$ Bakhtawar-92, $\mathrm{V}_{4}=$ Fakhre-e-Sarhad, and $\mathrm{V}_{5}=$ Lucky J-03)were allotted to main plots. While five different seed rates $\left(\mathrm{S}_{1}=\right.$ $60, S_{2}=80, S_{3}=100, S_{4}=120$, and $S_{5}=140$ $\mathrm{kg} \mathrm{ha}^{-1}$ ) were allocated to subplots. The experiment was laid out in a split plot design with four replications. Experiment was conducted on a well prepared seedbed. Net plot size of $4 \times 1.8 \mathrm{~m}^{2}$ was kept with six rows per plot. The fertilizer dose of $90 \mathrm{~kg}$ Phosphorus and $120 \mathrm{~kg} \mathrm{~N} \mathrm{ha}^{-1}$ was applied in the form of D.A.P and Urea. The nitrogen level $\left(120 \mathrm{~kg} \mathrm{ha}^{-1}\right)$ was split in two equal doses at $60 \mathrm{~kg} \mathrm{ha}^{-1}$. First dose of nitrogen (60 $\mathrm{kg} \mathrm{ha}^{-1}$ ) was applied to whole experimental plot uniformly with full dose of phosphorus $\left(90 \mathrm{~kg} \mathrm{ha}^{-1}\right)$ at the time of land preparation. $2^{\text {nd }}$ dose of nitrogen (60 $\mathrm{kg} \mathrm{ha}^{-1}$ ) was applied at tillering stage.

Adequate plant protection measures were made during the crop growing period. Keeping in view the soil condition and physical appearance of crop, five numbers of irrigations were applied to all the plots uniformly so that the wheat crop may not be damaged. Hand weeding was done to keep the crop free of weeds. Data was recorded on number of tillers, grains spike ${ }^{-1}$, leaf area index, thousand grains weight, biological and grain yields. For net income economic analysis was performed. At maturity four rows of the plot were harvested and tied into small bundle for sun drying for about one week. The dried bundles were threshed for collection of grain yield.
Statistical analysis of the data was done at $1 \%$ level of probability using Duncan's Multiple Range Test (DMRT) to test the difference between the individual means.

[1]

\section{Results}

Tillers $\mathbf{~ m}^{-2}$

Data presented in table 1 indicated that different wheat varieties had significant $(\mathrm{P}$ $\leq 0.05)$ effect on tillers $\mathrm{m}^{-}{ }^{2}$. Data showed that maximum (377) tillers $\mathrm{m}^{-2}$ were noted sown with variety Fakhre-e-Sarhad $\left(\mathrm{V}_{4}\right)$, followed by plots sown with Bakhtawar-92 and Lakki J03, which remained statistically similar to $\mathrm{V}_{4}$, while minimum (263) tillers $\mathrm{m}^{-2}$ were produced when plots were sown with Nasir-2K $\left(\mathrm{V}_{1}\right)$. The data further showed that different seed rates had significant affected tillers $\mathrm{m}^{-2}$. It is evident from the data that maximum tillers $\mathrm{m}^{-2}$ (369) were noted when plots were seeded with $120 \mathrm{~kg} \mathrm{ha}^{-1}\left(\mathrm{~S}_{4}\right)$, while minimum tillers $\mathrm{m}^{-2}$ (314) were recorded when $60 \mathrm{~kg} \mathrm{ha}^{-1}$ seed rate was used $\left(S_{1}\right)$. The data also indicated that interaction between wheat varieties and seed rate was significantly affected. Data showed that maximum (420.25) tillers $\mathrm{m}^{-2}$ were noted when variety Fakhre-e-Sarhad sown at the rate of $120 \mathrm{~kg}$ $\mathrm{ha}^{-1}$ seed rate $\left(\mathrm{V}_{4} \mathrm{~S}_{4}\right)$, while minimum tillers $\mathrm{m}^{-2}$ were noted from variety Nasir-2K and seeded with 60,80 and $100 \mathrm{~kg} \mathrm{ha}^{-1}$ (235, 245 and 252), which were statistically similar. Wheat varieties had significant effect on tillers. These results are in agreement with [2]. The differences among tillers $\mathrm{m}^{-2}$ of the varieties may be due to the inherent genetic potential for tillering as well as differences in the number of plants emerged per unit area. The data further showed that different seed rates had significant effect on tillers. These results are also reported by Khokar et al. [3] and Yoon et al. [4] who found maximum tillering at higher seed rates then at lower seed rates. The tillering potential was much higher at higher seed rate, when compared to lower seed rate. It might be due to that the number of tillers $\mathrm{m}^{-2}$ decreased with increase in seeding rate, because, by 
increasing seed rate per unit area, the inter plant competition for space, nutrient, moisture and sun light increases which results in lower tillers $\mathrm{m}^{-2}$. The data also indicated that interaction between wheat varieties and seed rate was significantly affected. [5] also reported similar results.

Table 1. Tillers $\mathrm{m}^{-2}$, number of grains spike $\mathrm{e}^{-1}$ and leaf area index as affected by various wheat varieties and different seed rates

\begin{tabular}{|c|c|c|c|}
\hline Treatments & Tillers $\mathbf{m}^{-2}$ & $\begin{array}{c}\text { Number of grains } \\
\text { spike }^{-1}\end{array}$ & Leaf area index \\
\hline \multicolumn{4}{|l|}{ A: Varieties } \\
\hline $\mathrm{V}_{1}($ Nasir $-2 \mathrm{k})$ & $263.50 \mathrm{C}$ & $54.40 \mathrm{C}$ & $2.76 \mathrm{C}$ \\
\hline $\mathrm{V}_{2}($ Salim - 2K $)$ & $319.75 \mathrm{~B}$ & $59.15 \mathrm{~B}$ & $3.44 \mathrm{~B}$ \\
\hline $\mathrm{V}_{3}$ (Bakhtawar-92) & $372.30 \mathrm{~A}$ & $61.85 \mathrm{~B}$ & $3.84 \mathrm{AB}$ \\
\hline $\mathrm{V}_{4}($ Fakhre-e-Sarhad $)$ & $377.30 \mathrm{~A}$ & $68.05 \mathrm{~A}$ & $4.10 \mathrm{~A}$ \\
\hline $\mathrm{V}_{5}($ Lakki J-03 $)$ & $368.50 \mathrm{~A}$ & $67.05 \mathrm{~A}$ & $3.59 \mathrm{~B}$ \\
\hline LSD $(\mathrm{P} \leq \mathbf{0 . 0 5})$ & 9.39 & 2.84 & 0.46 \\
\hline \multicolumn{4}{|l|}{ B: Seed Rate } \\
\hline $\mathrm{S}_{1}\left(60 \mathrm{~kg} \mathrm{ha}^{-1}\right)$ & $314.05 \mathrm{D}$ & $59.55 \mathrm{C}$ & $2.92 \mathrm{~B}$ \\
\hline $\mathrm{S}_{2}\left(80 \mathrm{~kg} \mathrm{ha}^{-1}\right)$ & $329.90 \mathrm{C}$ & $60.15 \mathrm{BC}$ & $3.50 \mathrm{~A}$ \\
\hline $\mathrm{S}_{3}\left(100 \mathrm{~kg} \mathrm{ha}^{-1}\right)$ & $334.80 \mathrm{C}$ & $63.10 \mathrm{AB}$ & $3.79 \mathrm{~A}$ \\
\hline $\mathrm{S}_{4}\left(120 \mathrm{~kg} \mathrm{ha}^{-1}\right)$ & $369.20 \mathrm{~A}$ & $65.30 \mathrm{~A}$ & $4.03 \mathrm{~A}$ \\
\hline $\mathrm{S}_{5}\left(140 \mathrm{~kg} \mathrm{ha}^{-1}\right)$ & $353.40 \mathrm{~B}$ & $62.40 \mathrm{~A}-\mathrm{C}$ & $3.50 \mathrm{~A}$ \\
\hline LSD $(\mathbf{P} \leq \mathbf{0 . 0 5})$ & 11.66 & 3.30 & 0.58 \\
\hline \multicolumn{4}{|l|}{ C: Interaction(AxB) } \\
\hline $\mathrm{V}_{1} \mathrm{~S}_{1}$ & $235.75 \mathrm{~L}$ & $50.25 \mathrm{~L}$ & $2.17 \mathrm{H}$ \\
\hline $\mathrm{V}_{1} \mathrm{~S}_{2}$ & $245.75 \mathrm{~L}$ & $52.50 \mathrm{KL}$ & $2.48 \mathrm{~F}-\mathrm{H}$ \\
\hline $\mathrm{V}_{1} \mathrm{~S}_{3}$ & $252.50 \mathrm{~L}$ & $55.00 \mathrm{~J}-\mathrm{K}$ & $2.85 \mathrm{E}-\mathrm{H}$ \\
\hline $\mathrm{V}_{1} \mathrm{~S}_{4}$ & $293.25 \mathrm{~K}$ & $58.25 \mathrm{H}-\mathrm{K}$ & $3.15 \mathrm{C}-\mathrm{H}$ \\
\hline $\mathrm{V}_{1} \mathrm{~S}_{5}$ & $290.25 \mathrm{~K}$ & $56.00 \mathrm{I}-\mathrm{L}$ & $2.99 \mathrm{C}-\mathrm{H}$ \\
\hline $\mathrm{V}_{2} \mathrm{~S}_{1}$ & $291.25 \mathrm{~K}$ & $56.00 \mathrm{I}-\mathrm{L}$ & $2.34 \mathrm{CH}$ \\
\hline $\mathrm{V}_{2} \mathrm{~S}_{2}$ & $308.25 \mathrm{JK}$ & $58.25 \mathrm{H}-\mathrm{K}$ & $3.66 \mathrm{~A}-\mathrm{F}$ \\
\hline $\mathrm{V}_{2} \mathrm{~S}_{3}$ & $319.75 \mathrm{IJ}$ & $58.50 \mathrm{H}-\mathrm{K}$ & $4.06 \mathrm{~A}-\mathrm{E}$ \\
\hline $\mathrm{V}_{2} \mathrm{~S}_{4}$ & $343.00 \mathrm{~F}-\mathrm{H}$ & $61.75 \mathrm{~F}-\mathrm{I}$ & $3.96 \mathrm{~A}-\mathrm{E}$ \\
\hline $\mathrm{V}_{2} \mathrm{~S}_{5}$ & $336.50 \mathrm{HI}$ & $61.25 \mathrm{~F}-\mathrm{J}$ & $3.36 \mathrm{~B}-\mathrm{H}$ \\
\hline $\mathrm{V}_{3} \mathrm{~S}_{1}$ & $357.25 \mathrm{D}-\mathrm{H}$ & $66.25 \mathrm{C}-\mathrm{E}$ & $3.36 \mathrm{~B}-\mathrm{H}$ \\
\hline $\mathrm{V}_{3} \mathrm{~S}_{2}$ & 368.75 C-E & $63.25 \mathrm{E}-\mathrm{H}$ & $3.42 \mathrm{~B}-\mathrm{H}$ \\
\hline $\mathrm{V}_{3} \mathrm{~S}_{3}$ & $372.75 \mathrm{~B}-\mathrm{D}$ & $64.00 \mathrm{D}-\mathrm{H}$ & 3.99 A-E \\
\hline $\mathrm{V}_{3} \mathrm{~S}_{4}$ & $395.00 \mathrm{~B}$ & $59.50 \mathrm{G}-\mathrm{J}$ & $4.79 \mathrm{~A}$ \\
\hline $\mathrm{V}_{3} \mathrm{~S}_{5}$ & 367.75 C-E & $56.25 \mathrm{I}-\mathrm{L}$ & $3.66 \mathrm{~A}-\mathrm{F}$ \\
\hline $\mathrm{V}_{4} \mathrm{~S}_{1}$ & $346.25 \mathrm{E}-\mathrm{H}$ & $65.75 \mathrm{C}-\mathrm{G}$ & $3.2 \mathrm{C}-\mathrm{H}$ \\
\hline $\mathrm{V}_{4} \mathrm{~S}_{2}$ & $365.00 \mathrm{C}-\mathrm{F}$ & $65.00 \mathrm{C}-\mathrm{G}$ & $4.16 \mathrm{~A}-\mathrm{D}$ \\
\hline $\mathrm{V}_{4} \mathrm{~S}_{3}$ & 368.75 C-E & $67.25 \mathrm{~B}-\mathrm{F}$ & $4.27 \mathrm{~A}-\mathrm{C}$ \\
\hline $\mathrm{V}_{4} \mathrm{~S}_{4}$ & $420.25 \mathrm{~A}$ & $74.00 \mathrm{~A}$ & $4.28 \mathrm{~A}-\mathrm{C}$ \\
\hline $\mathrm{V}_{4} \mathrm{~S}_{5}$ & $386.25 \mathrm{BC}$ & 68.25 A-E & $4.61 \mathrm{AB}$ \\
\hline $\mathrm{V}_{5} \mathrm{~S}_{1}$ & 339.75 G-I & $59.50 \mathrm{G}-\mathrm{J}$ & $3.51 \mathrm{~A}-\mathrm{G}$ \\
\hline $\mathrm{V}_{5} \mathrm{~S}_{2}$ & $361.75 \mathrm{D}-\mathrm{G}$ & $61.75 \mathrm{E}-\mathrm{I}$ & 3.79 A-E \\
\hline $\mathrm{V}_{5} \mathrm{~S}_{3}$ & $360.25 \mathrm{D}-\mathrm{G}$ & $70.75 \mathrm{~A}-\mathrm{C}$ & $3.78 \mathrm{~A}-\mathrm{F}$ \\
\hline $\mathrm{V}_{5} \mathrm{~S}_{4}$ & $394.50 \mathrm{~B}$ & $73.00 \mathrm{AB}$ & 3.99 A-E \\
\hline $\mathrm{V}_{5} \mathrm{~S}_{5}$ & $386.25 \mathrm{BC}$ & 70.25 A-D & $2.89 \mathrm{D}-\mathrm{H}$ \\
\hline LSD $(P \leq 0.05)$ & 11.66 & 6.34 & 1.30 \\
\hline
\end{tabular}

Means followed by different letters are significantly different from one another at $\mathrm{P} \leq 0.05$

Number of grains spike ${ }^{-1}$

Statistical analysis of the data perused in table 1 revealed that different wheat varieties were significantly affected 
number of grains spike ${ }^{-1}$. Highest number of grains (68) were noted sown with variety Fakhre-e-Sarhad $\left(\mathrm{V}_{4}\right)$, followed by plots sown with Lakki J03 (67 number of grains spike $^{-1}$ ), which was statistically similar to $\mathrm{V}_{4}$, while lowest (54) number of grains spike $^{-1}$ were produced when plots were sown with Nasir-2K $\left(\mathrm{V}_{1}\right)$. Data further revealed that different seed rates had significant effect on number of rains spike ${ }^{-}$ ${ }^{1}$. It is evident from the data that during 2003-04, maximum (65) number of grains spike $^{-1}$ were noted when plots were seeded with $120 \mathrm{~kg} \mathrm{ha}^{-1}\left(\mathrm{~S}_{4}\right)$, while minimum number of grains spike $^{-1}$ (59) were recorded when $60 \mathrm{~kg} \mathrm{ha}^{-1}$ seed rate was used $\left(S_{1}\right)$. The data also indicated that interaction between wheat varieties and seed rate was significantly affected. The potential of wheat spike is determined by the number of grains spike ${ }^{-1}$ which is an important yield component of grain yield. Statistical analysis of the data revealed that different wheat varieties were significantly affected number of grains spike $^{-1}$. The greater differences in number of grains spike $^{-1}$ of the five varieties showed greater genetic variability among the varieties for reproductive sink capacities of the varieties and differences in ear size [6]. Data further revealed that different seed rates had significant effect on number of rains spike 1. Similar results were also reported by [79] who reported that higher seed rates produced significant decrease in the number of grains spike ${ }^{-1}$. The increase in number of grains spike ${ }^{-1}$ with decrease in seed rate might be due to the plant nutrients present in the soil were enough for the vegetative growth and grain formation when there were less number of plants unit area $^{-1}$. They were less competitive for all essential elements as compared to the greater number of plants unit area ${ }^{-1}$. The data also indicated that interaction between wheat varieties and seed rate was significantly affected. These results are in agreement with [6]

\section{Leaf area index}

Analysis of data presented in table 1 showed that different wheat varieties had significant $(\mathrm{P} \leq 0.05)$ effect on leaf area index. Maximum leaf area index (4.10) was noted from plots sown with variety Fakhree-Sarhad $\left(\mathrm{V}_{4}\right)$, while minimum leaf area index (2.76) was recorded when plots were sown with Salim-2K $\left(\mathrm{V}_{2}\right)$. The data further showed that different seed rates had significant effect on leaf area index. It is evident from the data that maximum leaf area index (4.03) was noted when plots were seeded with $120 \mathrm{~kg} \mathrm{ha}^{-1}\left(\mathrm{~S}_{4}\right)$, while minimum leaf area index (2.92) was recorded when $60 \mathrm{~kg} \mathrm{ha}^{-1}$ seed rate was used $\left(\mathrm{S}_{1}\right)$. Data also indicated that interaction between wheat varieties and seed rate was significantly affected. Data showed that maximum leaf area index (4.79) was noted when variety Fakhre-eSarhad sown at the rate of $120 \mathrm{~kg} \mathrm{ha}^{-1}$ seed rate $\left(\mathrm{V}_{4} \mathrm{~S}_{4}\right)$, while minimum leaf area index (2.17) was noted by variety Nasir-2K seeded with $60 \mathrm{~kg} \mathrm{ha}^{-1}\left(\mathrm{~V}_{1} \mathrm{~S}_{1}\right)$. Analysis of data showed that different wheat varieties had significant effect on leaf area index. These results are also reported by [2].The difference among leaf area index may be the genetic potential and duration of its stages for vegetative and reproductive development. The data further showed that different seed rates had significant effect on leaf area index. Similar results were also reported by [10]. This might be due to long vegetation growth in low seeded plots than higher seeded ones. The seeding rate at 140 $\mathrm{kg} \mathrm{ha}^{-1}$ decreased the leaf area index due to greater competition among the plants for the limited sunlight and available nutrients in the soil. Data also indicated that interaction between wheat varieties and seed rate was significantly affected. It may to greater competition among the plants to the limited sunlight and available nutrients in the soil for leaf area index. As leaf area index depend upon tillers $\mathrm{m}^{-2}$ and leaf area tiller $^{-1}$, the differences in leaf area of the crop under different irrigation and seed rates may be due to interaction of internal genetic factors with environmental factor especially light and water status of the soil. 


\section{0-grain weight (g)}

Different wheat varieties showed a significant $(\mathrm{P} \leq 0.05)$ effect on 1000 -grain weight presented in table 2. Heaviest grains $(45.24 \mathrm{~g})$ were recorded sown with variety Fakhre-e-Sarhad $\left(\mathrm{V}_{4}\right)$, statistically similar to variety Lakki J03 (44.90 g), while lightest grains (40.43 g) were recorded by varieties Nasir-2K $\left(\mathrm{V}_{1}\right)$. Analysis of the data further revealed that different seed rates had significant effect on leaf area index. Maximum 1000-grains weight (45.33 g) was noted when plots were seeded with $120 \mathrm{~kg} \mathrm{ha}^{-1}\left(\mathrm{~S}_{4}\right)$, while minimum 1000 -grains weight $(41.45 \mathrm{~g})$ was recorded when $60 \mathrm{~kg} \mathrm{ha}^{-1}$ seed rate was used $\left(\mathrm{S}_{1}\right)$. The data also indicated that interaction between wheat varieties and seed rate was significantly affected. Maximum 1000grains weight (47.33 g) was obtained when variety Fakhre-e-Sarhad sown at the rate of $120 \mathrm{~kg} \mathrm{ha}^{-1}$ seed rate $\left(\mathrm{V}_{4} \mathrm{~S}_{4}\right)$, while minimum 1000-grains weight (38.35 g) was noted from variety Nasir-2K and seeded with $60 \mathrm{~kg} \mathrm{ha}^{-1}\left(\mathrm{~V}_{1} \mathrm{~S}_{1}\right)$. Different wheat varieties showed a significant effect on 1000-grain weight. Similar results are also stated by [6]. The differences in varieties may be due to variation in the potential grain size of the varieties, variation in leaf area specially the flag leaf area and may be due to variation in reproductive sink intensity as a result of physiological parameters which determined seed size in different varieties.

Analysis of the data further revealed that different seed rates had significant effect on leaf area index. The results obtained agree with findings of [11] who also reported that 1000 grain weight decreased with increasing in seeding densities.

It may be due to the variation in spikes $\mathrm{m}^{-2}$, because as spikes population increase, the amount of assimilates to be translocated to spike by each plant per unit area decrease and thus resulted in less 1000 grain weight under light seeding densities. The data also indicated that interaction between wheat varieties and seed rate was significantly affected. Similar results were also reported by [6].

\section{Grain yield ( $\left.\mathrm{kg} \mathrm{ha}^{-1}\right)$}

Statistical analysis of the data perused in table 2 revealed that different wheat varieties had significant $(\mathrm{P} \leq 0.05)$ effect on grain yield. Highest grain yield $\left(4022 \mathrm{~kg} \mathrm{ha}^{-}\right.$ 1) was produced by variety Fakhre-eSarhad $\left(\mathrm{V}_{4}\right)$, while all other varieties recorded lowest grain yield which were statistically similar to each other. Data further revealed that different seed rates had significant effect on grain yield. It is evident from the data that maximum grain yield (4222 $\mathrm{kg} \mathrm{ha}^{-1}$ ) was recorded when plots were seeded with $120 \mathrm{~kg} \mathrm{ha}^{-1}\left(\mathrm{~S}_{4}\right)$, while minimum grain yield $\left(3037 \mathrm{~kg} \mathrm{ha}^{-1}\right)$ was recorded when $60 \mathrm{~kg} \mathrm{ha}^{-1}$ seed rate was used $\left(S_{1}\right)$. The data also indicated that interaction between wheat varieties and seed rate was significantly affected. Data showed that maximum grain yield $(4676 \mathrm{~kg}$ $\mathrm{ha}^{-1}$ ) was obtained when variety Fakhre-eSarhad sown at the rate of $120 \mathrm{~kg} \mathrm{ha}^{-1}$ seed rate $\left(\mathrm{V}_{4} \mathrm{~S}_{4}\right)$, while minimum grain yield $\left(2932 \mathrm{~kg} \mathrm{ha}^{-1}\right)$ was recorded from variety Nasir-2K seeded with $140 \mathrm{~kg} \mathrm{ha}^{-1}$. Data revealed that different wheat varieties had significant effect on grain yield. Similar results were also reported by, [12-14]. The differences among grain yields of the 5varieties may be due to the variation in genetic makeup of the varieties and may have resulted from differences in yield components and partitioning of assimilates to grains. Data further revealed that different seed rates had significant effect on grain yield. These results are in agreement with [8-16] who reported that grain yield increased as seed rate increased and the highest grain yield was noted in plots seeded at of $120 \mathrm{~kg} \mathrm{ha}^{-1}$. The data also indicated that interaction between wheat varieties and seed rate was significantly affected. Similar results were also reported by [6]. 
Shah et al.

Table 2. 1000-grain weight, grain yield and biological yield as affected by various wheat varieties and different seed rates

\begin{tabular}{|c|c|c|c|}
\hline Treatments & $\begin{array}{c}\text { 1000-grain } \\
\text { weight }\end{array}$ & Grain yield $\left(\mathrm{kg} \mathrm{ha}^{-1}\right)$ & Biological yield $\left(\mathrm{kg} \mathrm{ha}^{-1}\right)$ \\
\hline \multicolumn{4}{|l|}{ A: Varieties } \\
\hline $\mathrm{V}_{1}($ Nasir - 2k) & $40.43 \mathrm{D}$ & $3542.30 \mathrm{~B}$ & $6333.84 \mathrm{D}$ \\
\hline $\mathrm{V}_{2}($ Salim - 2K) & $43.48 \mathrm{C}$ & $3524.90 \mathrm{~B}$ & $10474.93 \mathrm{C}$ \\
\hline $\mathrm{V}_{3}($ Bakhtawar-92) & $44.27 \mathrm{~B}$ & $3519.60 \mathrm{~B}$ & $13590.18 \mathrm{~B}$ \\
\hline $\mathrm{V}_{4}($ Fakhre-e-Sarhad $)$ & $45.24 \mathrm{~A}$ & $4022.50 \mathrm{~A}$ & $16660.92 \mathrm{~A}$ \\
\hline $\mathrm{V}_{5}($ Lakki J-03 ) & $44.90 \mathrm{~A}$ & $3460.15 \mathrm{~B}$ & $16041.03 \mathrm{AB}$ \\
\hline LSD $(\mathbf{P} \leq 0.05)$ & 0.51 & 331.30 & 2582.00 \\
\hline \multicolumn{4}{|l|}{ B: Seed Rate } \\
\hline $\mathrm{S}_{1}\left(60 \mathrm{~kg} \mathrm{ha}^{-1}\right)$ & $41.45 \mathrm{C}$ & $3037.15 \mathrm{C}$ & $9540.00 \mathrm{C}$ \\
\hline $\mathrm{S}_{2}\left(80 \mathrm{~kg} \mathrm{ha}^{-1}\right)$ & $43.89 \mathrm{~B}$ & $3381.10 \mathrm{BC}$ & $11959.61 \mathrm{~B}$ \\
\hline $\mathrm{S}_{3}\left(100 \mathrm{~kg} \mathrm{ha}^{-1}\right)$ & $44.11 \mathrm{~B}$ & $3673.00 \mathrm{~B}$ & $12353.24 \mathrm{~B}$ \\
\hline $\mathrm{S}_{4}\left(120 \mathrm{~kg} \mathrm{ha}^{-1}\right)$ & $45.30 \mathrm{~A}$ & $4222.80 \mathrm{~A}$ & $15030.53 \mathrm{~A}$ \\
\hline $\mathrm{S}_{5}\left(140 \mathrm{~kg} \mathrm{ha}^{-1}\right)$ & $43.55 \mathrm{~B}$ & $3855.40 \mathrm{~B}$ & $12549.57 \mathrm{~B}$ \\
\hline LSD $(P \leq 0.05)$ & 1.16 & 357.60 & 2416.00 \\
\hline \multicolumn{4}{|l|}{ C: Interaction (A x B) } \\
\hline $\mathrm{V}_{1} \mathrm{~S}_{1}$ & $38.35 \mathrm{G}$ & $2932.50 \mathrm{I}$ & $5164.53 \mathrm{~J}$ \\
\hline $\mathrm{V}_{1} \mathrm{~S}_{2}$ & $40.40 \mathrm{FG}$ & 3306.25 E-I & $5913.53 \quad \mathrm{IJ}$ \\
\hline $\mathrm{V}_{1} \mathrm{~S}_{3}$ & $41.08 \mathrm{EF}$ & $3756.25 \mathrm{~B}-\mathrm{H}$ & $6807.38 \quad$ H-J \\
\hline $\mathrm{V}_{1} \mathrm{~S}_{4}$ & $42.25 \mathrm{D}-\mathrm{F}$ & $4059.00 \mathrm{~A}-\mathrm{E}$ & $6903.00 \quad \mathrm{H}-\mathrm{J}$ \\
\hline $\mathrm{V}_{1} \mathrm{~S}_{5}$ & $40.05 \mathrm{FG}$ & $3657.50 \mathrm{~B}-\mathrm{I}$ & $6880.78 \quad$ H-J \\
\hline $\mathrm{V}_{2} \mathrm{~S}_{1}$ & $41.23 \mathrm{EF}$ & $2972.75 \mathrm{HI}$ & 8767.25 G-J \\
\hline $\mathrm{V}_{2} \mathrm{~S}_{2}$ & 43.78 B-D & $3237.25 \mathrm{~F}-\mathrm{I}$ & 10509.63 E-J \\
\hline $\mathrm{V}_{2} \mathrm{~S}_{3}$ & $43.83 \mathrm{~B}-\mathrm{D}$ & 3617.50 C-I & 11124.75 D-I \\
\hline $\mathrm{V}_{2} \mathrm{~S}_{4}$ & $45.30 \mathrm{~A}-\mathrm{C}$ & $4188.75 \mathrm{~A}-\mathrm{D}$ & $11732.97 \mathrm{C}-\mathrm{H}$ \\
\hline $\mathrm{V}_{2} \mathrm{~S}_{5}$ & $43.25 \mathrm{C}-\mathrm{E}$ & 3608.25 C-I & 10240.05 F-J \\
\hline $\mathrm{V}_{3} \mathrm{~S}_{1}$ & $41.03 \mathrm{EF}$ & $3036.00 \mathrm{HI}$ & $12366.88 \mathrm{C}-\mathrm{G}$ \\
\hline $\mathrm{V}_{3} \mathrm{~S}_{2}$ & $44.80 \mathrm{BC}$ & 3197.00 G-I & 11049.75 D-I \\
\hline $\mathrm{V}_{3} \mathrm{~S}_{3}$ & $44.28 \mathrm{~B}-\mathrm{D}$ & 3363.75 E-I & $13013.88 \mathrm{~B}-\mathrm{G}$ \\
\hline $\mathrm{V}_{3} \mathrm{~S}_{4}$ & $45.85 \mathrm{AB}$ & $4163.75 \mathrm{~A}-\mathrm{D}$ & $18203.25 \mathrm{AB}$ \\
\hline $\mathrm{V}_{3} \mathrm{~S}_{5}$ & $45.38 \mathrm{~A}-\mathrm{C}$ & $3837.50 \mathrm{~B}-\mathrm{G}$ & $13317.13 \mathrm{~B}-\mathrm{G}$ \\
\hline $\mathrm{V}_{4} \mathrm{~S}_{1}$ & 42.20 D-F & 3191.25 G-I & $16376.88 \mathrm{~A}-\mathrm{D}$ \\
\hline $\mathrm{V}_{4} \mathrm{~S}_{2}$ & $45.45 \mathrm{~A}-\mathrm{C}$ & 3473.75 D-I & $15589.38 \mathrm{~A}-\mathrm{F}$ \\
\hline $\mathrm{V}_{4} \mathrm{~S}_{3}$ & $45.85 \mathrm{AB}$ & $4350.00 \mathrm{~A}-\mathrm{C}$ & $15136.69 \mathrm{~A}-\mathrm{F}$ \\
\hline $\mathrm{V}_{4} \mathrm{~S}_{4}$ & $47.33 \mathrm{~A}$ & $4676.25 \mathrm{~A}$ & $19535.16 \mathrm{~A}$ \\
\hline $\mathrm{V}_{4} \mathrm{~S}_{5}$ & $45.38 \mathrm{~A}-\mathrm{C}$ & $4421.25 \mathrm{AB}$ & $16666.50 \mathrm{~A}-\mathrm{C}$ \\
\hline $\mathrm{V}_{5} \mathrm{~S}_{1}$ & 44.46 B-D & 3053.25 G-I & $13364.25 \mathrm{~B}-\mathrm{G}$ \\
\hline $\mathrm{V}_{5} \mathrm{~S}_{2}$ & $45.03 \mathrm{BC}$ & 3191.25 G-I & $16735.75 \mathrm{~A}-\mathrm{C}$ \\
\hline $\mathrm{V}_{5} \mathrm{~S}_{3}$ & $45.53 \mathrm{~A}-\mathrm{C}$ & 3277.50 E-I & 15683.50A-E \\
\hline $\mathrm{V}_{5} \mathrm{~S}_{4}$ & $45.78 \mathrm{AB}$ & $4026.25 \mathrm{~A}-\mathrm{F}$ & $17778.28 \mathrm{AB}$ \\
\hline $\mathrm{V}_{5} \mathrm{~S}_{5}$ & 43.70 B-D & $3752.50 \mathrm{~B}-\mathrm{H}$ & $15643.38 \mathrm{~A}-\mathrm{E}$ \\
\hline LSD $(P \leq 0.05)$ & 2.27 & 799.60 & 5402.00 \\
\hline
\end{tabular}

Means followed by different letters are significantly different from one another at $\mathrm{P} \leq 0.05$ 


\section{Biological yield ( $\left.\mathrm{kg} \mathrm{ha}^{-1}\right)$}

Statistical analysis of data given in table 3 showed that different wheat varieties had significant $(\mathrm{P} \leq 0.05)$ effect on biological yield. It is clear from the data that maximum biological yield (16660 kg ha-1) was recorded from plots sown with variety Fakhre-e-Sarhad $\left(\mathrm{V}_{4}\right)$, while minimum biological yield $\left(6333 \mathrm{~kg} \mathrm{ha}^{-1}\right)$ was recorded when plots were sown with Nasir$2 \mathrm{~K}\left(\mathrm{~V}_{1}\right)$. The data further showed that different seed rates had significantly $(\mathrm{P} \leq$ $0.05)$ affected biological yield. It is evident from the data that maximum biological yield $\left(15030 \mathrm{~kg} \mathrm{ha}^{-1}\right)$ was noted when plots were seeded with $120 \mathrm{~kg} \mathrm{ha}^{-1}\left(\mathrm{~S}_{4}\right)$, while minimum biological yield (9540 $\mathrm{kg} \mathrm{ha}^{-1}$ ) was recorded when $60 \mathrm{~kg} \mathrm{ha}^{-1}$ seed rate was used $\left(\mathrm{S}_{1}\right)$. The same trend was followed. Data also indicated that interaction between wheat varieties and seed rate was affected. Data showed that maximum biological yield (19535 $\mathrm{kg} \mathrm{ha}^{-1}$ ) was noted when variety Fakhre-e-Sarhad sown at the rate of $120 \mathrm{~kg} \mathrm{ha}^{-1}$ seed rate $\left(\mathrm{V}_{4} \mathrm{~S}_{4}\right)$, while minimum biological yield $\left(5164 \mathrm{~kg} \mathrm{ha}^{-1}\right)$ was produced by variety Nasir-2K seeded with $60 \mathrm{~kg} \mathrm{ha}^{-1}\left(\mathrm{~V}_{1} \mathrm{~S}_{1}\right)$. Statistical analysis of data showed that different wheat varieties had significant effect on biological yield. The differences in biological yield of varieties may be due to variation in their genetic potential for seasonal dry matter accumulation. The data further showed that different seed rates had significantly affected biological yield. These results are in agreement with [7] stated that the increase in biological yield with higher seed rate might be due to more number of plants per unit area, though with reduced tillers. Data also indicated that interaction between wheat varieties and seed rate was affected. Biological yield is a product of number of tillers $\mathrm{m}^{-2}$ and tillers weight including spike weight and grain weight. The differences in biological yield could be variation in tillers $\mathrm{m}^{-2}$ and tiller weight. Both of these have been differentially affected by the soil and environmental conditions.

\section{Economic analysis}

Data presented in table 3 indicate the economic analysis of wheat as affected by various varieties and different seed rates. Wheat varieties showed a significant increase in net monetary grain presented in table 3. It is clear from the data of the growing season that when plots were sown with variety Fakhre-e-Sarhad produced maximum (Rs. 61921.00) net income, while variety Nasir-2K noted minimum (Rs. 40109.00) net profit. When plots were seeded with $120 \mathrm{~kg} \mathrm{ha}$ produced maximum (Rs. 62119.00) net income, while plots in which seed rate was used at $60 \mathrm{~kg} \mathrm{ha}^{-1}$ noted minimum (Rs. 30755.00) net profit. In case of interaction between varieties and seed rate, maximum (Rs. 66719.00) net profit was noted in the combination of variety Fakhre-e-Sarhad and $120 \mathrm{~kg} \mathrm{ha}^{-1}$ seed rate, while minimum (Rs. 30755.00) was noted from plots in which variety Nasir 2k seeded with $120 \mathrm{~kg}$ $\mathrm{ha}^{-1}$ and no nitrogen fertilizer was applied. The data also revealed that BCR (benefit cost ratio) was higher when variety Fakhree-Sarhad was sown produced maximum (4.99) BCR, while variety Nasir-2K get minimum (3.98) BCR. When seed rate was applied at $120 \mathrm{~kg} \mathrm{ha}^{-1}$ gave (5.18) BCR, while when plots were seeded with $60 \mathrm{~kg}$ $\mathrm{ha}^{-1}$ noted minimum (3.77) BCR. When the interaction studied, it was observed that when variety Fakhre-e-Sarhad seeded with $120 \mathrm{~kg} \mathrm{ha}^{-1}$ and fertilized with $120 \mathrm{~kg} \mathrm{~N} \mathrm{ha}^{-}$ 1 produced maximum (5.83) BCR, while minimum (3.28) BCR was noted when plots were seeded with $60 \mathrm{~kg} \mathrm{ha}^{-1}$ with variety Nasir-2K.

Highest (499.49) marginal rate of return was noted from variety Fakhre-e-Sarhad, while lowest (397.54) marginal rate of return was recorded by variety Nasir-2K. Similarly when plots were seeded with 120 $\mathrm{kg} \mathrm{ha}^{-1}$ noted maximum (5.18) marginal rate of return, while minimum (377.24) marginal rate of return was obtained from those pots in which seed rate was used at 60 $\mathrm{kg} \mathrm{ha}{ }^{-1}$. The data further revealed that interaction showed a significant variation among varieties and seed rate. Maximum 
(582.57) marginal rate of return was noted from the combination of variety Fakhre-eSarhad and $120 \mathrm{~kg} \mathrm{ha}^{-1}$ seed rate, while minimum (328.15) marginal rate of return was noted from variety Nasir-2K seeded with $60 \mathrm{~kg} \mathrm{ha}^{-1}$.

Table 3. Economic analysis of wheat as affected by various irrigation and nitrogen levels

\begin{tabular}{|c|c|c|c|c|c|c|c|c|c|}
\hline \multirow{2}{*}{$\begin{array}{l}\text { Treatment } \\
\text { S } \\
\text { A: } \\
\text { Varieties }\end{array}$} & \multicolumn{2}{|c|}{$\begin{array}{c}\text { Wheat Yield } \\
\left(\mathrm{kg} \mathrm{ha}^{-1}\right)\end{array}$} & \multicolumn{2}{|c|}{$\begin{array}{l}\text { Income } \\
\left(\text { Rs. ha }^{-1}\right)\end{array}$} & \multirow{2}{*}{$\begin{array}{l}\text { Gross } \\
\text { Income } \\
\left(\text { Rs.ha }^{-1}\right)\end{array}$} & \multirow{2}{*}{$\begin{array}{l}\text { Total } \\
\text { Expendit } \\
\text { ure } \\
\left(\text { Rs. ha }{ }^{-1}\right)\end{array}$} & \multirow{2}{*}{$\begin{array}{l}\text { Net } \\
\text { Income } \\
(\text { Rs. ha-1) }\end{array}$} & \multirow[t]{2}{*}{ BCR } & \multirow[t]{2}{*}{$\begin{array}{l}\text { MRR } \\
\%\end{array}$} \\
\hline & $\begin{array}{l}\text { Grai } \\
\mathrm{n}\end{array}$ & Straw & Grain & Straw & & & & & \\
\hline $\mathrm{V}_{1}$ & 3542 & 6334 & 42504 & 11085 & 53589 & 13480 & 40109 & 3.98 & 397.54 \\
\hline $\mathrm{V}_{2}$ & 3525 & 10475 & 42300 & 18331 & 60631 & 14320 & 46311 & 4.23 & 423.40 \\
\hline $\mathrm{V}_{3}$ & 3520 & 13590 & 42240 & 23783 & 66023 & 14960 & 51063 & 4.41 & 441.33 \\
\hline $\mathrm{V}_{4}$ & 4022 & 16661 & 48264 & 29157 & 77421 & 15500 & 61921 & 4.99 & 499.49 \\
\hline $\mathrm{V}_{5}$ & 3460 & 16041 & 41520 & 28072 & 69592 & 16040 & 53552 & 4.34 & 433.87 \\
\hline \multicolumn{10}{|l|}{$\begin{array}{l}\text { B: Seed } \\
\text { rate }(\mathrm{kg} \\
\left.\mathrm{ha}^{-1}\right)\end{array}$} \\
\hline$S_{1}(60)$ & 3037 & 11208 & 36444 & 19614 & 56058 & 14860 & 41198 & 3.77 & 377.24 \\
\hline $\mathrm{S}_{2}(80)$ & 3281 & 11960 & 39372 & 20930 & 60302 & 14860 & 45442 & 4.06 & 405.80 \\
\hline $\mathrm{S}_{3}(100)$ & 3673 & 12353 & 44076 & 21618 & 65694 & 14860 & 50834 & 4.42 & 442.09 \\
\hline $\mathrm{S}_{4}(120)$ & 4223 & 15030 & 50676 & 26303 & 76979 & 14860 & 62119 & 5.18 & 518.03 \\
\hline $\mathrm{S}_{5}(140)$ & 3856 & 12550 & 46272 & 21963 & 68235 & 14860 & 53375 & 4.59 & 459.19 \\
\hline \multicolumn{10}{|l|}{$\begin{array}{l}\text { C: } \\
\text { Interaction } \\
(\text { A } \times \text { B })\end{array}$} \\
\hline $\mathrm{V}_{1} \mathrm{~S}_{1}$ & 2933 & 5165 & 35196 & 9039 & 44235 & 13480 & 30755 & 3.28 & 328.15 \\
\hline $\mathrm{V}_{1} \mathrm{~S}_{2}$ & 3306 & 5914 & 39672 & 10350 & 50022 & 13480 & 36542 & 3.71 & 371.08 \\
\hline $\mathrm{V}_{1} \mathrm{~S}_{3}$ & 3756 & 6807 & 45072 & 11912 & 56984 & 13480 & 43504 & 4.23 & 422.73 \\
\hline $\mathrm{V}_{1} \mathrm{~S}_{4}$ & 4059 & 6903 & 48708 & 12080 & 60788 & 13480 & 47308 & 4.51 & 450.95 \\
\hline $\mathrm{V}_{1} \mathrm{~S}_{5}$ & 3658 & 6881 & 43896 & 12042 & 55938 & 13480 & 42458 & 4.15 & 414.97 \\
\hline $\mathrm{V}_{2} \mathrm{~S}_{1}$ & 2973 & 8767 & 35676 & 15342 & 51018 & 14320 & 36698 & 3.56 & 356.27 \\
\hline $\mathrm{V}_{2} \mathrm{~S}_{2}$ & 3237 & 10510 & 38844 & 18393 & 57237 & 14320 & 42917 & 4.00 & 399.70 \\
\hline $\mathrm{V}_{2} \mathrm{~S}_{3}$ & 3618 & 11125 & 43416 & 19469 & 62885 & 14320 & 48565 & 4.39 & 439.14 \\
\hline $\mathrm{V}_{2} \mathrm{~S}_{4}$ & 4189 & 11733 & 50268 & 20533 & 70801 & 14320 & 56481 & 4.94 & 494.42 \\
\hline $\mathrm{V}_{2} \mathrm{~S}_{5}$ & 3608 & 10240 & 43296 & 17920 & 61216 & 14320 & 46896 & 4.27 & 427.49 \\
\hline $\mathrm{V}_{3} \mathrm{~S}_{1}$ & 3036 & 12367 & 36432 & 21642 & 58074 & 14960 & 43114 & 3.88 & 388.20 \\
\hline $\mathrm{V}_{3} \mathrm{~S}_{2}$ & 3197 & 11050 & 38364 & 19338 & 57702 & 14960 & 42742 & 3.86 & 385.71 \\
\hline $\mathrm{V}_{3} \mathrm{~S}_{3}$ & 3364 & 13014 & 40368 & 22775 & 63143 & 14960 & 48183 & 4.22 & 422.08 \\
\hline $\mathrm{V}_{3} \mathrm{~S}_{4}$ & 4164 & 18203 & 49968 & 31855 & 81823 & 14960 & 66863 & 5.47 & 546.95 \\
\hline $\mathrm{V}_{3} \mathrm{~S}_{5}$ & 3838 & 13317 & 46056 & 23305 & 69361 & 14960 & 54401 & 4.64 & 463.64 \\
\hline $\mathrm{V}_{4} \mathrm{~S}_{1}$ & 3191 & 16377 & 38292 & 28660 & 66952 & 15500 & 51452 & 4.32 & 431.95 \\
\hline $\mathrm{V}_{4} \mathrm{~S}_{2}$ & 3474 & 15589 & 41688 & 27281 & 68969 & 15500 & 53469 & 4.45 & 444.96 \\
\hline $\mathrm{V}_{4} \mathrm{~S}_{3}$ & 4350 & 15137 & 52200 & 26490 & 78690 & 15500 & 63190 & 5.08 & 507.68 \\
\hline $\mathrm{V}_{4} \mathrm{~S}_{4}$ & 4676 & 19535 & 56112 & 34186 & 90298 & 15500 & 74798 & 5.83 & 582.57 \\
\hline $\mathrm{V}_{4} \mathrm{~S}_{5}$ & 4421 & 16667 & 53052 & 29167 & 82219 & 15500 & 66719 & 5.30 & 530.45 \\
\hline $\mathrm{V}_{5} \mathrm{~S}_{1}$ & 3053 & 13364 & 36636 & 23387 & 60023 & 16040 & 43983 & 3.74 & 374.21 \\
\hline $\mathrm{V}_{5} \mathrm{~S}_{2}$ & 3191 & 16736 & 38292 & 29288 & 67580 & 16040 & 51540 & 4.21 & 421.32 \\
\hline $\mathrm{V}_{5} \mathrm{~S}_{3}$ & 3278 & 15684 & 39336 & 27447 & 66783 & 16040 & 50743 & 4.16 & 416.35 \\
\hline $\mathrm{V}_{5} \mathrm{~S}_{4}$ & 4026 & 18778 & 48312 & 32862 & 81174 & 16040 & 65134 & 5.06 & 506.07 \\
\hline $\mathrm{V}_{5} \mathrm{~S}_{5}$ & 3753 & 15643 & 45036 & 27375 & 72411 & 16040 & 56371 & 4.51 & 451.44 \\
\hline
\end{tabular}




\section{Authors' contribution}

Conceived and designed the experiments: WA Shah, Performed the experiments: WA Shah, Z Hayat \& Ikramullah, Analyzed the data: WA Shah, Contributed reagents/ materials/ analysis tools: S Anwar \& B Iqbal, Wrote the paper: WA Shah

\section{References}

1. Steel RGD \& Torrie JH (1980). Principals and procedures of statistics. McGraw Hill Book Co Inc New York.

2. Suhail MS (2002). Growth, yield and physiological characteristics of wheat varieties planted on different dates. M.Sc. thesis, Deptt Agro NWFP Agric Uni Peshawar, Pakistan.

3. Khokar MA, Shaikh MS, Siddique M \& Nazar MS (1985). Effect of different seeding densities and nitrogen levels on the yield of 100 wheat genotypes. Pak $J$ Agri 6(3):150-152.

4. Yoon EB, Yoon YH, Kwon YU, Yoon KB \& Shin MG (1991). Studies on fertilizer levels, row spacing and sowing rate using the plot drill seeder in winter wheat. Res. Rural Development In, Upland and Industrial Crops, 33:6571.

5. Najma K (2004). Preliminary wheat varietal trail under moisture stress condition. B.Sc Review Paper. Deptt. of Agron. NWFP Agric Uni Peshawar Pakistan.

6. Khakkar KM (2003). Irrigation and nlevels for wheat varieties under bedplanting system. PhD thesis. Dept of Agronomy NWFP Agric Uni Pesh Pakistan.

7. Marwat AQ, Khalil SK, Wazir AL \& Iqbal M (1989). Effect of land preparation and seeding rates on plant height and straw yield on wheat. Sarhad J Agri 5(3): 273-278.
8. Nazir SM, Zafar I, Ghazanfar A \& Akhtar M (1982). Response of wheat to soil moisture stress at early growth stage on high water table soil. Faislabad J Agri 83-86.

9. Chatha MR, Mukhtar A \& Gill MA (1986). Yield of wheat cultivars as affected by different seed rates under irrigated conditions. Pak J Agri 7(4): 241-24.

10. Ibrar K (1999). Effect of seed rates and nitrogen levels on wheat. M. Sc thesis, Deptt Agro NWFP Agric Uni Peshawar, Pakistan.

11. Mansab AK, Sheikh MS \& Siddique M (1985). Effect of different seeding densities and nitrogen levels on the yield of two wheat genotypes. Pak $J$ Agri 6(3): 150-152.

12. Ijaz AK, Bakht J, Wajid SA, Khan NM \& Inamullah (2002). Effect of seed rate on the yield and yield components of wheat under irrigated conditions of Peshawar. Asian J Plant Sci 1:513-515.

13. Azra Y \& Shah SH (2000). Quantitative and qualitative response of three wheat varieties to nitrogen applications. Pak J Bio Sci 3 (10): 1545-1546.

14. Kamal AMA, Islam MR, Chowdhary BLD \& MalequeTalukder MA (2003). Yield performance and grain quality of wheat varieties grown under rainfed and irrigated conditions. Asian J Plant Sci 2(3):358-360.

15. Mujahid ZH (1972). Effect of row spacing and seed rates on the growth and yield of wheat variety Chenab-70. MSc Agric Thesis. Agric Uni Faisalabad.

16. Hameed E, Wajid SA, Shad AA, Bakht J \& Muhammad T (2003). Effect of different planting dates, seed rates and nitrogen levels on wheat. Asian J Plant Sci 2(6): 464-474. 